\title{
ПРОБЛЕМЫ СТРОЕНИЯ И АБРАЗИИ БЕРЕГОВЫХ ДЮН СЕВЕРНОГО ПОБЕРЕЖЬЯ ЧУДСКОГО ОЗЕРА
}

Характерной геоморфологической чертой северного побережья Чудского озера является широкое развитие эоловых форм рельефа. Возникновение и развитие береговых дюн непосредственно связаны с характером и интенсивностью развития береговых процессов, которые влияют на условия и направленность эоловой деятельности. Развитие эоловых процессов и форм рельефа определяется и обусловливается целым рядом факторов: ветровым режимом, количеством осадков, составом и количеством исходного материала, геоморфологическими условиями местности, влиянием растительности, человеческой деятельностью и др.

Хотя береговые процессы в пределах крупных озер в основном аналогичны морским, имеются все-таки некоторые различия, обусловленные главным образом замкнутостью водоема, его морфометрическими особенностями и специфическим гидрометеорологическим режимом. K сожалению, береговые процессы Чудского озера до сих пор мало изучены. Так как данная статья посвящена изучению строения и развития эоловых форм северного побережья озера, а дюны органически связаны с пляжем и активно участвуют в береговых процессах, автор останавливается на некоторых вопросах динамики береговой зоны.

На формирование береговой зоны северного побережья Чудского озера оказывает влияние целый комплекс факторов, но важнейшим из них является уровенный режим озера. Как известно, в закрытых водоемах, длинная ось которых совпадает с направлением преобладающих ветров, в наветренной части озер время от времени заметно поднимается уровень воды. Уровень воды при сильных ветрах поднимается тем больше, чем мельче водоем. Чудское озеро мелководно (средняя глубина 7 м), в течение года здесь преобладают ветры юго-западного и южного направлений. Если учесть еще пологость подводного берегового склона $\left(i_{2}=0,012\right)$, то вполне достоверно, что поднятие уровня воды даже менее чем на 0,5 м причиняет ущерб подножью дюн.

Уже в середине прошлого столетия Г. Гельмерсен (Helmersen, 1864) подчеркивал, что сезонные колебания уровня воды влияют на динамику береговой зоны. Он выделил два вида колебаний - кратковременные, вызванные ветром (т. е. сгоны и нагоны), и сезонные, связанные с изменением водного баланса озера. Он отметил, что при сильных южных ветрах уровень на северном берегу озера может подниматься на 45-60 см и вода при этом доходить до подножья дюн. Теперь, когда имеются многолетние наблюдения за уровнем озера 99 лет - (Гидрометеорологический ..,., 1983), можно сказать, что кроме выделенных Г. Гельмерсеном причин колебаний существует еще одна и именно, долговременные колебания уровня воды. Это значит, что в жизни озера чередуются многоводные и маловодные периоды длительностью 5-13 лет (рис. 1). А. Яани (Jaаni, 1973) называет их циклич- 


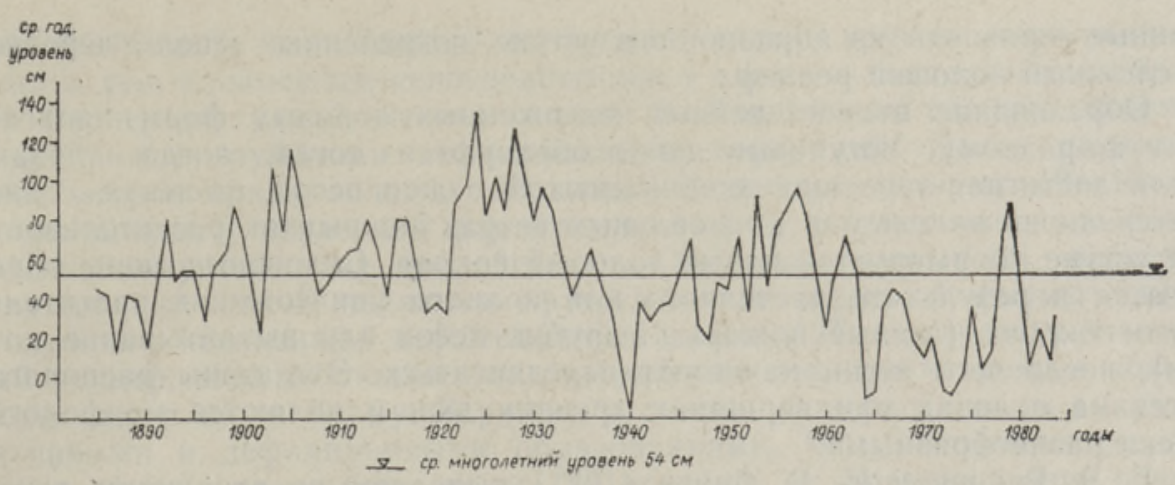

Рис. 1. Среднегодовой уровень воды Чудского озера в 1885-1980 rr.

ными колебаниями. Примером этого служит период 1922-1933 гг., когда средднегодовой уровень воды в течение 11 лет стоял выше среднегодового многих лет, причем два года - 1924 и 1928 - оказались экстремальными. По данным литературы (Wellner, 1928), катастрофическими были также 1840 и 1844 гг. Маловодный период отмечался с 1964 по 1977 гг. (13 лет), а в 1978 г. начался опять цикл с повышенным уровнем воды. Весной 1979 г. происходили обширные разрушения северного побережья озера. Среднегодовой уровень стоит низким начиная с 1980 г.

По наблюдениям автора (лето 1982 и 1983 гг.) абразия дюн и берегового уступа в настоящее время продолжается. Действие таких долгопериодических колебаний уровенного режима озера на динамику берегов причиняет изменения в морфологии береговой зоны, особенно в периоды с повышенным уровнем воды. Судя по структуре береговых дюн северного побережья, которые содержат обычно несколько погребенных почвенных горизонтов, можно предполагать, что такие же сильные колебания уровня воды имели место в течение всей геологической истории озера.

Как было сказано, дюны оказывают активное влияние на береговые процессы. Определенная роль в формировании современной береговой зоны северного побережья Чудского озера принадлежит крупным дюнам, находящимся между Алайыэ и Смольницей. При высоком уровне воды и сильных ветрах дюны, поднимающиеся непосредственно с пляжа, оказывают влияние на пляжевые процессы. С одной стороны, это заключается в том, что зона заплеска перемещается в сторону суши, и энергия волн распределяется на более узкой площади, что в свою очередь вызывает размыв пляжа. В таком случае дюны действуют как морские стены. С другой стороны, дюны являются источником песчаного материала, который используется для перестройки профиля пляжа и образования подводных валов, и представляет собой природный барьер для штормовых волн и заплеска. Естественно, что самые заметные изменения береговой зоны происходят именно на этом участке побережья (рис. 2).

Образование и развитие береговых дюн и берегового уступа северного побережья Чудского озера является длительным и сложным процессом. Рассматриваемые дюны отличаются от типичных голоценовых дюн морского побережья своей морфологией. Они имеют ступенчатое строение - большинство более молодых дюн образовалось за счет более старых, и располагаются на абразионном уступе (уступовые дюны) или на склонах древних дюн (склоновые дюны) (Orviku, 1933). O переотложении и преобразовании дюн свидетельствуют погребенные поч- 
венные горизонты на абразионном уступе, погребенные стволы деревьев и сложный эоловый рельеф.

Образование второстепенных наложенных эоловых форм происходит по-разному. Уступовые дюны образуются тогда, когда абразия волн достигает заросших дюн. Вымытый с дюн песок, высыхая, становится вновь эоловым и при сильных ветрах покрывает растительность на уступе. Формируется новый эоловый покров. Склоновые дюны образуются в результате частичного или полного уничтожения растительного покрова (лесные пожары, вырубка лесов или вытаптывание почвы), после чего пески начинают передвигаться. Эти дюны располагаются на склонах или вершинах древних дюн и являются морфологически разнообразными.

Г. Э. Рейнек и И. Б. Сингх (1981) выделяют во вторичном дюнообразовании еще одну фазу. Образовавшиеся таким путем дюны осаждения формируются в условиях привноса песка в районы, с богатой растительностью. Осаждение песка связано с тем, что деревья преграждают путь нагруженным песчаным материалом ветрам. Наличие растительного покрова способствует фиксации песка. Смена направления дующих ветров, а также воздействие экстремальных штормовых ветров могут сильно изменить форму дюн, в результате чего формируется сложная система песчаных впадин и возвышенностей. Судя по строению и морфологии, в пределах полосы дюн северного побережья Чудского озера наблюдаются все вышеуказанные типы эолового рельефа. Преобладающими в ландшафте являются глубокие впадины и куполовидные формы. Содействие дефляции и аккумуляции привели к тому, что склоны дюн северного побережья Чудского озера коренным образом отличаются от типичных береговых дюн с более пологим наветренным склоном, и крутым - подветренным. Первоначальный крутой подветренный склон сохраняется лишь местами, пологий наветренный склон - очень редко.

Полоса береговых дюн по.своей морфологии подразделяется па гряды и дюнные поля. Здесь приводится морфологическая характеристика более маркантных и интересных дюнных полей. Дюнные поля Смольницы, Ремнику и Карьямаа (рис. 2) морфологически весьма сходны. Их сложный рельеф характеризует долговременные изменения в структуре дюн. Расположены они по обеим сторонам устья реки, но более мощные скопления эолового песка, как правило, сконцентрированы на левом берегу. Это свидетельствует о значительной роли передвижения речных наносов во время образования дюнного ландшафта. Пляж уз-

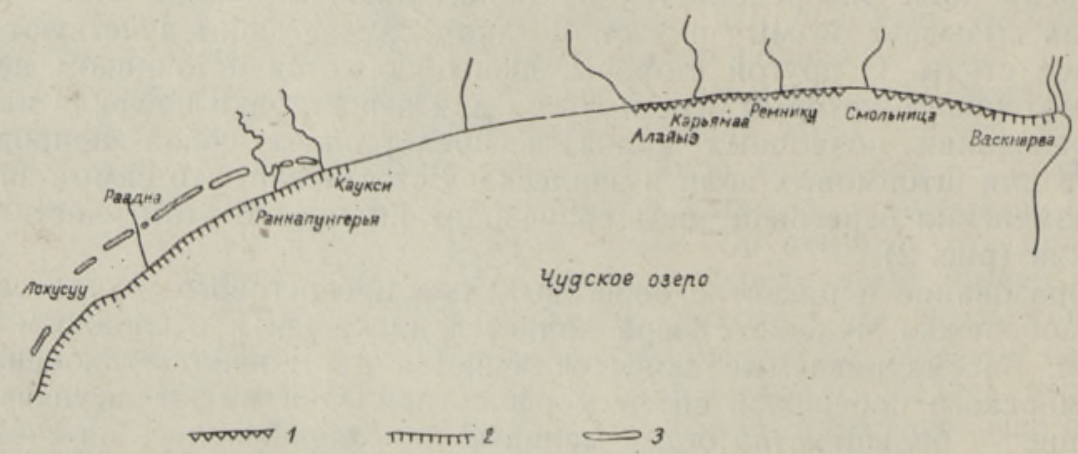

Рис. 2. Схема расположения дюнных полей. 1 - абразионный берег; 2 - зарастающий берег, 3 - старые дюны. 
кий, 6-10 м (в зависимости от уровня воды), крутые наветренные склоны дюн начинаются непосредственно с пляжа и подвергаются абразии. За первой грядой, высота которой 5-8 м, обычно следует область выдувания с глубокими дефляционными воронками. Далее расположена вторая гряда эоловых образований, высота которых 12-15 м. Дюны покрыты неплотной растительностью и подвержены довольно интенсивному эоловому воздействию. Основным элементом рельефа этих дюнных полей являются крутосклонные округлой формы дюны и глубокие междюнные дефляционные воронки. Первоначальный эоловый рельеф, видимо, полностью переработан водой и ветром, а новые дюны имеют иную форму. Вершина и склоны дюн расчленены аккумулятивными и дефляционными образованиями. Часто встречаются недавно сформировавшиеся дюны. В отличие от древних, они почти всегда меньших размеров и имеют строго выраженную эоловую форму - валообразную, барханную или параболическую. Например, ширина недавно образовавшейся на вершине старой бархановидной дюны составляет 6 м, а высота лишь 1,5 м. Размеры валообразной дюны на наветренном склоне также невелики: длина 10 м, ширина 5 м, высота 2 м. Эти дюны образовались при южных и юго-запіадных ветрах, т. е. при преобладающих ветрах. Их образование осуществлялось довольно активным эоловым переносом песка в пределах этих дюнных полей.

Самое высокое дюнное поле находится восточнее устья р. Алайыэ, достигая высоты 20 м. Наветренный склон первой дюнной гряды здесь тоже крутой и абрадированный, растительность на склоне уничтожена. Вторая, более высокая гряда следует непосредственно за первой. Растительный покров здесь более устойчивый (сосновый лес), абразии и дефляции подвержен лишь обращенный к озеру наветренный склон дюнной гряды. Поэтому морфология дюн здесь выражена более четко встречаются валообразные дюны, длинные оси которых вытянуты в северо-восточном - юго-западном направлении.

Западнее устья р. Раннапунгерья находится своеобразное дюнное поле Ярвевялья, состоящее как будто из двух частей (рис. 3). Севернее шоссе Йхви-Муствеэ расположены т. н. древние дюны, которые, по-видимому, являются береговыми образованиями какой-то фазы Малой Пейпси (Мийдел, 1981). Перед дюнами расположена местами заболоченная терраса, которая находится на 5-6 м выше нынешнего уровня

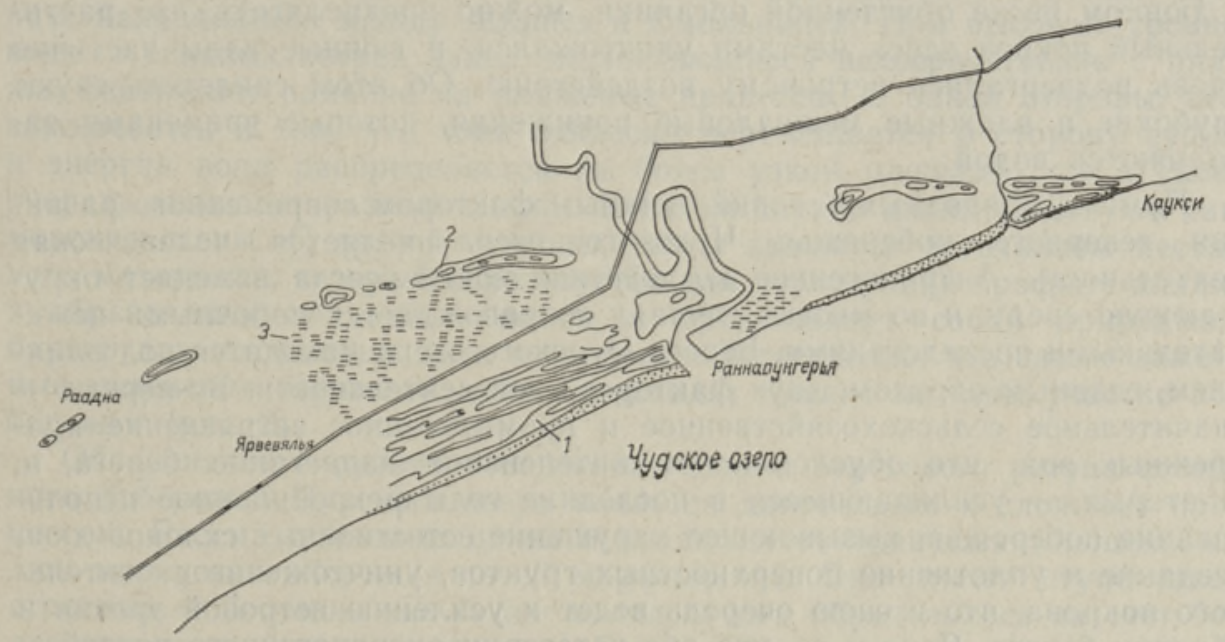

Рис. 3. Геоморфологическая схема дюнного поля Раннапунгерья. 1 - дюнное поле Ярвевялья; 2 - старые дюны; 3 - заболоченный участок. 
озера. Между террасой и озером находится вторая часть дюнного поля Ярвевялья, состоящая из серии низких и параллельных друг другу дюнных валов (Martin, 1984).

Древние дюны по морфологии сходны с береговыми дюнами Чудского озера. В.западной части, где дюны более высокие (до 9 м), основными являются куполовидные формы, расчлененные множеством котловин выдувания. Противоположные склоны по форме существенно не различаются, хотя подветренные склоны в большинстве случаев более крутые $\left(20-32^{\circ}\right)$, чем наветренные $\left(10-20^{\circ}\right)$. По всей вероятности и здесь определенную роль сыграло совместное действие абразии и дефляции.

Вторая часть дюнного поля Ярвевялья характеризуется режимом отступания. На этой прибрежной равнине расположено около 15 береговых валов, протягивающихся почти параллельно современной береговой линии. Ширина зоны развития береговых валов составляет около 750 м, а длина вдоль берега в среднем 2 км. Отдельные валы находятся друг от друга на расстоянии $40-50$ м. Их высота $1-2$ м. Валы четко выражены в рельефе, что в комплексе с эоловыми отложениями свидетельствует о сложном генезисе этих образований. Первоначальное формирование береговых валов могло происходить в пределах береговой зоны. Благодаря непрерывному отступанию берега и продолжающемуся поступлению песчаного материала происходило формирование все новых валов. Так как отступание озера было равномерным, без длительных остановок, то образовавшиеся валы являются сходными по морфологии и строению.

На заключительных этапах развития береговых валов важную роль играл ветер, эти валы можно отнести к типу прибрежно-дюнных. По всей вероятности, эоловая деятельность не была долговременной и дюны довольно быстро зарастали. На участие ветра в формировании этих валов указывает и факт, что кварцевые зерна из дюнных валов так же хорошо окатаны, как и зерна прибрежных дюн. По морфологии дюнные валы однообразны. Уклоны противоположных склонов мало отличаются друг от друга $\left(2-8^{\circ}\right)$; валы все же имеют характерную для эоловой аккумуляции форму - наветренные склоны $\left(4-9^{\circ}\right)$ более пологие, чем подветренные $\left(6-23^{\circ}\right)$. Высота валов $1-2$ м, вершина плоская. Ширина колеблется от 20 до 30 метров. В настоящее время валы покрыты стабильным растительным покровом, но судя по почвообразующему процессу (слой подзола лишь 5-10 см) и наличи! в дюнном песке обугленной органики, можно предполагать, что растительный покров здесь местами уничтожался, и дюнные валы частично вновь подвергались ветровому воздействию. Об этом свидетельствуют глубокие и влажные межваловые понижения, которые временами заполняются водой.

Помимо природных условий, важным фактором современного развития северного побережья Чудского озера является человеческая деятельность. Антропогенное воздействие почти всегда изменяет окружающую среду, и во многих случаях согіровождается побочными нежелательными последствиями. Берега Чудского озера находятся под влиянием, главным образом, двух факторов этой деятельности. Во-первых значительное сэльскохозяйственное и промышленное загрязнение прибрежных вод, что обусловливает интенсивное зарастание берега, и, во-вторых - усиливающееся в последние годы рекреационное использование побережья, вызывающее нарушение естественных склонов дюн, оседание и уплотнение поверхностных грунтов, уничтожение растительного покрова, что в свою очередь ведет к усилению ветровой эрозии и абразии берега. Ясно и то, что обе категории антропогенного воздействия взаимосвязаны. Например, зарастающие берега теряют свою рекреационную функцию. Как следствне - увеличивается антропоген- 


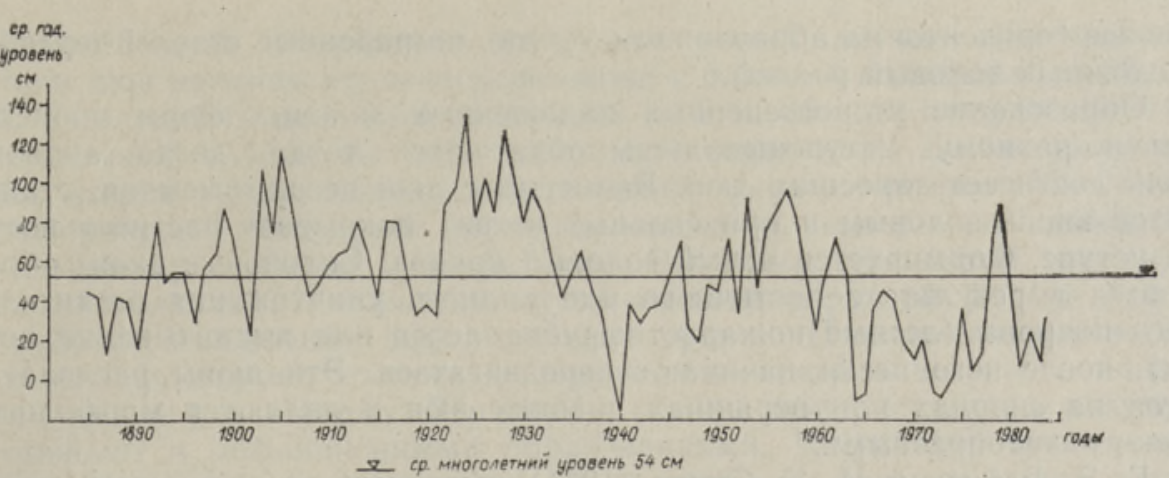

Рис. 1. Среднегодовой уровень воды Чудского озера в 1885-1980 гг.

ными колебаниями. Примером этого служит период 1922-1933 гг., когда среднегодовой уровень воды в течение 11 лет стоял выше среднегодового многих лет, причем два года - 1924 и 1928 - оказались экстремальными. По данным литературы (Wellner, 1928), катастрофическими были также 1840 и 1844 гг. Маловодный период отмечался с 1964 по 1977 гг. (13 лет), а в 1978 г. начался опять цикл с повышенным уровнем воды. Весной 1979 г. происходили обширные разрушения северного побережья озера. Среднегодовой уровень стоит низким начиная с 1980 г.

По наблюдениям автора (лето 1982 и 1983 гг.) абразия дюн и берегового уступа в настоящее время продолжается. Действие таких долгопериодических колебаний уровенного режима озера на динамику берегов причиняет изменения в морфологии береговой зоны, особенно в периоды с повышенным уровнем воды. Судя по структуре береговых дюн северного побережья, которые содержат обычно несколько погребенных почвенных горизонтов, можно предполагать, что такие же сильные колебания уровня воды имели место в течение всей геологической истории озера.

Как было сказано, дюны оказывают активное влияние на береговые процессы. Определенная роль в формировании современной береговой зоны северного побережья Чудского озера принадлежит крупным дюнам, находящимся между Алайыэ и Смольницей. При высоком уровне воды и сильных ветрах дюны, поднимающиеся непосредственно с пляжа, оказывают влияние на пляжевые процессы. С одной стороны, это заключается в том, что зона заплеска перемещается в сторону суши, и энергия волн распределяется на более узкой площади, что в свою очередь вызывает размыв пляжа. В таком случае дюны действуют как морские стены. С другой стороны, дюны являются источником песчаного материала, который используется для перестройки профиля пляжа и образования подводных валов, и представляет собой природный барьер для штормовых волн и заплеска. Естественно, что самые заметные изменения береговой зоны происходят именно на этом участке побережья (рис. 2).

Образование и развитие береговых дюн и берегового уступа северного побережья Чудского озера является длительным и сложным процессом. Рассматриваемые дюны отличаются от типичных голоценовых дюн морского побережья своей морфологией. Они имеют ступенчатое строение - большинство более молодых дюн образовалось за счет более старых, и располагаются на абразионном уступе (уступовые дюны) или на склонах древних дюн (склоновые дюны) (Orviku, 1933). О переотложении и преобразовании дюн свидетельствуют погребенные поч- 
венные горизонты на абразионном уступе, погребенные стволы деревьев и сложный эоловый рельеф.

Образование второстепенных наложенных эоловых форм происходит по-разному. Уступовые дюны образуются тогда, когда абразия волн достигает заросших дюн. Вымытый с дюн песок, высыхая, становится вновь эоловым и при сильных ветрах покрывает растительность на уступе. Формируется новый эоловый покров. Склоновые дюны образуются в результате частичного или полного уничтожения растительного покрова (лесные пожары, вырубка лесов или вытаптывание почвы), после чего пески начинают передвигаться. Эти дюны располагаются на склонах или вершинах древних дюн и являются морфологически разнообразными.

Г. Э. Рейнек и И. Б. Сингх (1981) выделяют во вторичном дюнообразовании еще одну фазу. Образовавшиеся таким путем дюны осаждения формируются в условиях привноса песка в районы с богатой растительностью. Осаждение песка связано с тем, что деревья преграждают путь нагруженным песчаным материалом ветрам. Наличие растительного покрова способствует фиксации песка. Смена направления дующих ветров, а также воздействие экстремальных штормовых ветров могут сильно изменить форму дюн, в результате чего формируется сложная система песчаных впадин и возвышенностей. Судя по строению и морфологии, в пределах полосы дюн северного побережья Чудского озера наблюдаются все вышеуказанные типы эолового рельефа. Преобладающими в ландшафте являются глубокие впадины и куполовидные формы. Содействие дефляции и аккумуляции привели к тому, что склоны дюн северного побережья Чудского озера коренным образом отличаются от типичных береговых дюн с более пологим наветренным склоном, и крутым - подветренным. Первоначальный крутой подветренный склон сохраняется лишь местами, пологий наветренный склон - очень редко.

Полоса береговых дюн по своей морфологии подразделяется на гряды и дюнные поля. Здесь приводится морфологическая характеристика более маркантных и интересных дюнных полей. Дюнные поля Смольницы, Ремнику и Карьямаа (рис. 2) морфологически весьма сходны. Их сложный рельеф характеризует долговременные изменения в структуре дюн. Расположены они по обеим сторонам устья реки, но более мощные скопления эолового песка, как правило, сконцентрированы на левом берегу. Это свидетельствует о значительной роли передвижения речных наносов во время образования дюнного ландшафта. Пляж уз-

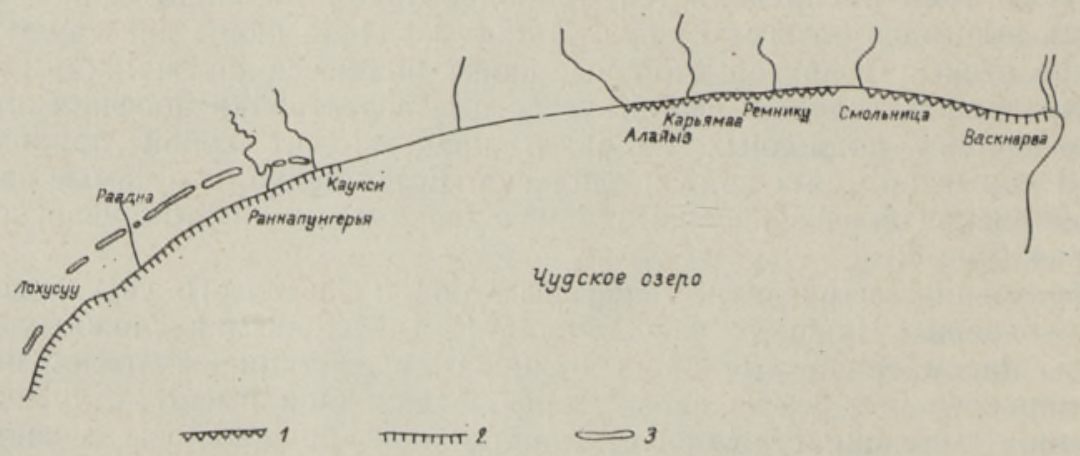

Рис. 2. Схема расположення дюнных полей. 1 - абразионный берег; 2 - зарастающий берег, 3 - старые дюны. 
кий, 6-10 м (в зависимости от уровня воды), крутые наветренные склоны дюн начинаются непосредственно с пляжа и подвергаются абразии. За первой грядой, высота которой $5-8$ м, обычно следует область выдувания с глубокими дефляционными воронками. Далее расположена вторая гряда эоловых образований, высота которых 12-15 м. Дюны покрыты неплотной растительностью и подвержены довольно интенсивному эоловому воздействию. Основным элементом рельефа этих дюнных полей являются крутосклонные округлой формы дюны и глубокие междюнные дефляционные воронки. Первоначальный эоловый рельеф, видимо, полностью переработан водой и ветром, а новые дюны имеют иную форму. Вершина и склоны дюн расчленены аккумулятивными и дефляционными образованиями. Часто встречаются недавно сформировавшиеся дюны. В отличие от древних, они почти всегда меньших размеров и имеют строго выраженную эоловую форму - валообразную, барханную или параболическую. Например, ширина недавно образовавшейся на вершине старой бархановидной дюны составляет 6 м, а высота лишь 1,5 м. Размеры валообразной дюны на наветренном склоне также невелики: длина 10 м, ширина 5 м, высота 2 м. Эти дюны образовались при южных и юго-западных ветрах, т. е. при преобладающих ветрах. Их образование осуществлялось довольно активным эоловым переносом песка в пределах этих дюнных полей.

Самое высокое дюнное поле находится восточнее устья р. Алайыэ, достигая высоты 20 м. Наветренный склон первой дюнной гряды здесь тоже крутой и абрадированный, растительность на склоне уничтожена. Вторая, более высокая гряда следует непосредственно за первой. Растительный покров здесь более устойчивый (сосновый лес), абразии и дефлящии подвержен лишь обращенный к озеру наветренный склон дюнной гряды. Поэтому морфология дюн здесь выражена более четковстречаются валообразные дюны, длинные оси которых вытянуты в северо-восточном - юго-западном направлении.

Западнее устья р. Раннапунгерья находится своеобразное дюнное поле Ярвевялья, состоящее как будто из двух частей (рис. 3). Севернее шоссе Йхви-Муствеэ расположены т. н. древние дюны, которые, по-видимому, являются береговыми образованиями какой-то фазы Малой Пейпси (Мийдел, 1981). Перед дюнами расположена местами заболоченная терраса, которая находится на 5-6 м выше нынешнего уровня

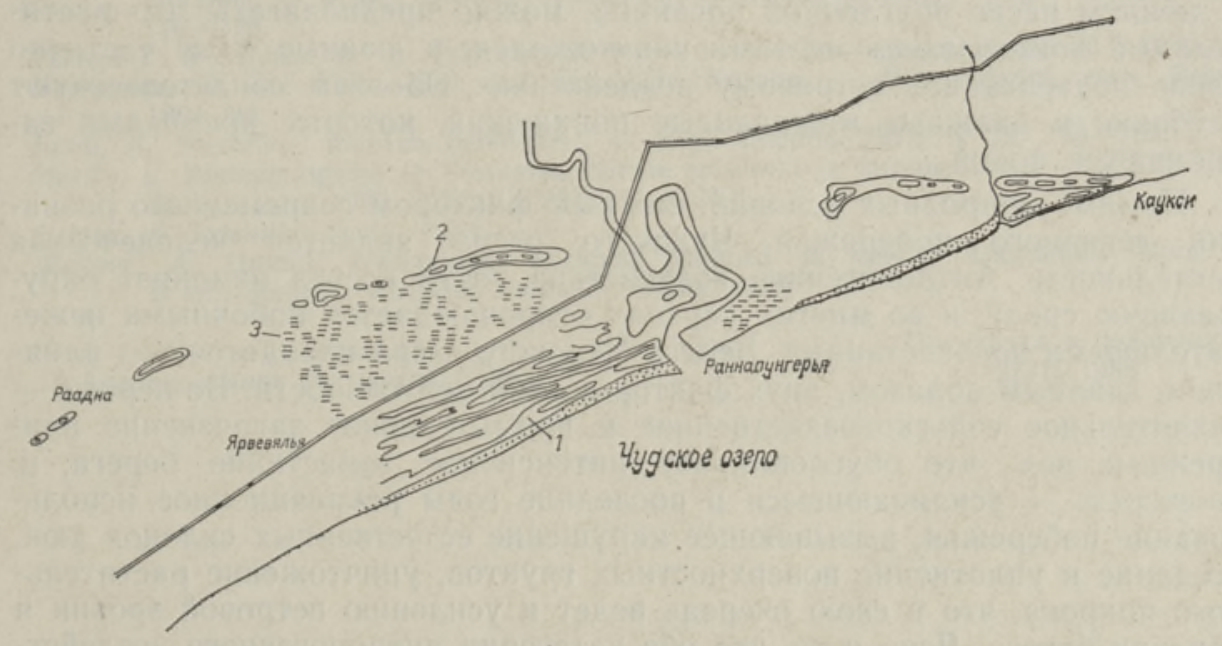

Рис. 3. Геоморфологическая схема дюнного поля Раннапунгерья. $I$ - дюнное поле Ярвевялья; 2 - старые дюны; 3 - заболоченный участок, 
озера. Между террасой и озером находится вторая часть дюнного поля Ярвевялья, состоящая из серии низких и параллельных друг другу дюнных валов (Martin, 1984).

Древние дюны по морфологии сходны с береговыми дюнами Чудского озера. В западной части, где дюны более высокие (до 9 м), основными являются куполопидные формы, расчлененные множеством котловин выдувания. Противоположные склоны по форме существенно не различаются, хотя подветренные склоны в большинстве случаев более крутые $\left(20-32^{\circ}\right)$, чем наветренные $\left(10-20^{\circ}\right)$. По всей вероятности и здесь определенную роль сыграло совместное действие абразии и дефляции.

Вторая часть дюнного поля Ярвевялья характеризуется режимом отступания. На этой прибрежной равнине расположено около 15 береговых валов. протягивающихся почти параллельно современной береговой линии. Ширина зоны развития береговых валов составляет около 750 м, а длина вдоль берега в среднем 2 км. Отдельные валы находятся друг от друга на расстоянии $40-50$ м. Их высота $1-2$ м. Валы четко выражены в рельефе, что в комплексе с эоловыми отложениями свидетельствует о сложном генезисе этих образований. Первоначальное формирование береговых валов могло происходить в пределах береговой зоны. Благодаря непрерывному отступанию берега и продолжающемуся поступлению песчаного материала происходило формирование все новых валов. Так как отступание озера было равномерным, без длительных остановок, то образовавшиеся валы являются сходными по морфологии и строению.

На заключительных этапах развития береговых валов важную роль играл ветер, эти валы можно отнести к типу прибрежно-дюнных. По всей вероятности, эоловая деятельность не была долговременной и дюны довольно быстро зарастали. На участие ветра в формировании этих валов указывает и факт, что кварцевые зерна из дюнных валов так же хорошо окатаны, как и зерна прибрежных дюн. По морфологии дюнные валы однообразны. Уклоны противоположных склонов мало отличаются друг от друга $\left(2-8^{\circ}\right)$; валы все же имеют характерную для эоловой аккумуляции форму - наветренные склоны $\left(4-9^{\circ}\right)$ более пологие, чем подветренные $\left(6-23^{\circ}\right)$. Высота валов $1-2$ м, вершина плоская. Ширина колеблется от 20 до 30 метров. В настоящее время валы покрыты стабильным растительным покровом, но судя по почвообразующему прощессу (слой подзола лишь 5-10 см) и наличию в дюнном песке обугленной органики, можно предполагать, что растительный покров здесь местами уничтожался, и дюнные валы частично вновь подвергались ветровому воздействию. Об этом свидетельствуют глубокие и влажные межваловые понижения, которые временами заполняются водой.

Помимо природных условий, важным фактором современного развития северного побережья Чудского озера является человеческая деятельность. Антропогенное воздействие почти всегда изменяет окружаюшую среду, и во многих случаях сопровождается побочными нежелательными последствиями. Берега Чудского озера находятся под влиянием, главным образом, двух факторов этой деятельности. Во-первых значительное ссльскохозяйственное и промыщленное загрязнение прибрежных вод, что обусловливает интенсивное зарастание берега, и, во-вторых - усиливающееся в последние годы рекреационное использование побережья, вызывающее нарушение естественных склонов дюн, оседание и уплотнение поверхностных грунтов, уничтожение растительного покрова, что в свою очередь ведет к усилению ветровой эрозии и абразии берега. Ясно и то, что обе категории антропогенного воздействия взаимосвязаны. Например, зарастающие берега теряют свою рекреационную функцию. Как следствие - увеличивается антропоген- 
ная нагрузка на другие участкй песчаного берега. Н̈аглядный пример в этом плане - г. Муствеэ, расположенный на берегу озера. Построенный в 20-х годах мол в устье р. Муствеэ обусловил аккумуляцию песчаных наносов к югу. Образовавшийся в тени мола довольно широкий пляж полностью удовлетворял потребности жителей. В последнее время этот участок и береговая зона в пределах города интенсивно зарастают тростником и кустарником. Жители города вынуждены теперь ездить на перенаселенный пляж в Каукси (самый близкий песчаный пляж).

Северное побережье Чудского озера на протяжении 40 киллометров (от Лохусуу до Васкнарва) является прекрасным местом отдыха. К настоящему времени участок в 12 км (10 км от Лохусуу до Кауксй и 2 км к западу от Васкнарва) уже частично потерял свои рекреационные функции из-за зарастания пляжа (рис. 2). Незаросшая часть пляжа постепенно уменьшается, а антропогенная нагрузка как раз на этот участок возрастает с каждым годом. Если мы за 40 лет сумели потерять $1 / 3$ песчаного пляжа, легко представить, что будет дальше возникшая бесконечная цепь причин и последствий в конечном счете приведут к уничтожению уникального ландшафта.

Существенно регулировать численность отдыхающих на такой обширной и интенсивно используемой территории, видимо, невозможно, поскольку приток отдыхающих «регулируется» в основном непроизвольно - доступностью, аттрактивностью и популярностью территории (Меллума и др., 1982). Так как популярность северного побережья Чудского озера возрастает из года в год, необходимо срочно принять меры для защиты этого красивого, но крайне неустойчивого ландшафта.

\section{ЛИТЕР А Т Р Р А}

Гидрометеорологический режим озер и водохранилищ СССР. Чудско-Псковское озеро. Л., 1983.

Меллума А. Ж., Рунгуле Р. Х., Эмсис И. В. Отдых на природе как природоохранная проблема. Рнга, 1982.

Мийдел A. О проблемах изучения неотектонических движений в Псковско-Чудской впадине. - В кн.: Донные отложения Псковско-Чудского озера. Таллин, 1981, $116-126$.

Рейнек Г. Э., Сингх И. Б. Обстановки терригенного осадконакопления. М., 1981.

Helmersen, G. Der Peipus-See und die obere Narova, - Beitr. Kennt. russ. Reichs. 1864,24

Jaani, A. Veerohkus muutub tsükliliselt. - Eesti Loodus, 1973, N 12, 758-764.

Martin, E. Rannapungerja ja Tõstamaa luidete ehitusest ja kujunemisest. - B кн.: EGS Aastaraamat 1980. Tallinn, 1984, 111-121.

Orviku, K. Tuiskliiv. Tartu, 1933.

Wellner, A. (toim.). Naroovajōe uurimise andmed ja veejôu kasutamise kava. В кн.: Sisevete uurimise andmed. Tallinn, 1928.

Институт геологии

Академии наук Эстонской ССР
Поступила в редакцию $27 /$ II 1985 


\section{PEIPSI POHJARANNIKU LUIDETE EHITUSEST JA ABRASIOONI PÖJUSTEST}

Peipsi põhjarannik piirneb luiteahelikuga, mis aeg-ajalt laienedes moodustab luitevälju. Arvestades luidete ja veepiiri vahele jäävat kitsast rannariba $(6-12 \mathrm{~m})$ ja rannanōlva suhtelist lamedust $\left(i_{2}=0,012\right)$, on tõenäoline, et juba vähem kui $50 \mathrm{~cm}$ kōrgune veepinna tõus võib esile kutsuda luidete abrasiooni. Järve veepinna lühiajalised ja tsüklilised kõikumised on üks tegureid, mis mõjustab oluliselt rannadünaamikat ning pōhjustab muutusi rannavööndi morfoloogias ja luidete ehituses. Peipsi põhjaranniku luited on ehituselt astmelised, s, t. nooremad on moodustunud vanemate arvel ja asetsevad vastavalt kas abrasiooniastangul vōi vanade luidete nōlvadel. On esitatud üksikute luiteväljade geomorfoloogilised kirjeldused (Smolnitsa, Remniku, Karjamaa, Alajōe, Rannapungerja). Peale looduslike tegurite mōjustab rannaprotsesse ja soodustab luidete abrasiooni ka inimtegevus, mis Peipsi põhjarannikul avaldub peamiselt kahe tegurina: esiteks rannavette sattunud pôllumajandus- ja tööstusreostus, mis pōhjustab rannavööndi kinnikasvamist, ja teiseks piirkonna üha suurenev puhkemajanduslik kasutamine.

\section{Ena MARTIN}

\section{THE STRUCTURE OF THE DUNES OF THE NORTHERN COAST OF LAKE PEIPSI AND REASONS FOR ABRASION}

The northern coast of L. Peipsi is surrounded by a dune ridge which forms dune fields by widening. Considering the narrow beach between the dunes and the water margin $(6-12 \mathrm{~m})$ and the relatively gentle coastal slope $\left(i_{2}=0.012\right)$, it may be assumed that a rise in the water level by even less than $50 \mathrm{~cm}$ may have caused an abrasion of the coastal dunes. The short-term and cyclic water level variations serve as a factor considerably affecting the coastal dynamics and causing changes in the morphology and structure of the coastal dunes. The dunes on the northern coast of L. Peipsi have a stepwise structure, i. e. the younger ones have been formed on account of the older dunes; they are correspondingly situated either on the abrasion scarp or on the slopes of the old dunes. Geomorphological descriptions of single dune fields (Smolnitsa, Remniku, Karjamaa, Alajōe, Rannapungerja) have been presented. The coastal processes and the abrasion of dunes are, besides natural circumstances, also influenced by human activity which, on the northern coast of L. Peipsi, is mostly represented by two factors: 1. agricultural and industrial pollution of the coastal water, causing an overgrowth of the coastal zone; 2 . the increasing usage of the region for recreational purposes. 